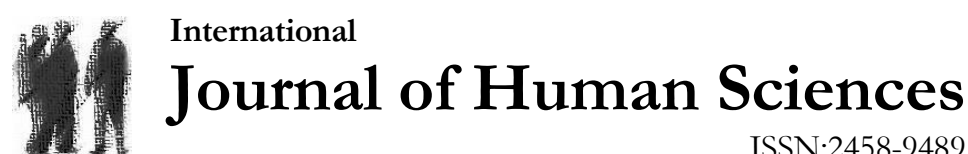

Volume 17 Issue 4 Year: 2020

\section{Involuntary (forced) migration in rural settlements and resettlement: Case of Konya - Bozkır Barrage Resettlement}

\author{
Süheyla Büyükşahin ${ }^{1}$
}

\begin{abstract}
Rural settlements that are shaped by the existence of the natural environment such as climate, topography, water resources, traditional buildings and gardens built with accessible construction materials found in the region, and organic structures in harmony with the natural environment are also cultural heritage areas. In this sense, preserving the traditional fabric of rural settlements and ensuring the continuity of rural life is important for sustainable development. The necessity of ensuring architectural identity and cultural sustainability in rural settlements that are faced with involuntary (forced) migration and whose projects are prepared for resettlement, as they may be adversely affected by the development projects carried out by the state, constitute the problematic of this study. Within the scope of this study, the Konya - Bozkır Barrage Resettlement Project prepared for the Dedemli village, which faces involuntary migration due to the construction of the Bozkır Barrage, is handled and evaluated with its positive and negative aspects. Based on the onsite examinations it is possible to mention that, although higher life standards are tried to be achieved in the resettlement project, both the overall planning of the project and the houses built with modern building materials in the exterior and interior exhibit a typology far from the traditional architectural typology and the socio-cultural, architectural, urban and economical continuity belonged to the place cannot be achieved. According to the results obtained from the field study, attention is drawn to the negative consequences of new resettlement projects produced on the basis of typical projects in terms of architectural identity and cultural sustainability, and the village design guidelines prepared for new villages are recommended to be applicable for villages that had to move and it is emphasized that principles should be put forward to ensure its continuity.
\end{abstract}

Keywords: Involuntary migration; rural settlements; resettlement; cultural sustainability; architectural identity, village design guidelines.

\footnotetext{
${ }^{1}$ Assist. Prof. Dr., Necmettin Erbakan University, Faculty of Engineering and Architecture, Department of Architecture, suheylabuyuksahin@gmail.com, (D) Orcid ID: 0000-0001-5869-3629
} 


\section{INTRODUCTION}

Rural settlements are settlements that exhibit a fabric shaped according to the topography and climate with local building materials, in the natural environment that meet the needs of the local people, have natural resources and influence areas and have cultural values. These settlements are an important part of our architectural culture in the natural environment and historical process as a whole with their agricultural activities, recreation activities, social structure, natural environment, housing unit and other urban facilities. In addition to the natural resource qualities, the buildings found their own identity that are similar with the material, color, form, facade layout, roofs, differentiate according to the physical environment and social structure they are placed in, and their coming together give the settlement the character of identifiability and determine the character of the rural settlement. In this sense, the loss of traditional environments means the disappearance of a culture. Since the design and planning studies for rural settlements in our country are mostly carried out at higher scales, the original settlement characteristics are ignored. While re-planning rural settlements, which are important cultural elements with their local identities, architectural conservation plays an important role in ensuring cultural continuity.

Since the investment projects for the development of the country are mostly aimed at the use of natural resources, rural settlements are directly affected by these planning decisions. These projects sometimes cause internal migration, sometimes external migration, affect job opportunities, destroy people's environment and natural resources, and cause cultural transformations. Although projects have many different social impacts, it is possible to say that the most important of these impacts is "involuntary (forced) migration". The phenomenon of involuntary migration, which is frequently caused by projects such as dams, highways and railways that require land acquisition, is the most concrete example of the effect of changing the environment by man.

The concept of resettlement, which is closely related to migration movements, is a political phenomenon that constitutes an important turning point in the lives of states and societies and therefore covers a long process when evaluated in terms of its results. Individual or mass displacement movements have performed very important functions in the formation and development of social structures throughout history. Therefore, the concept of resettlement is much broader than the concept of settlement, which is defined as the collective or dispersed living of people in different types of settlements. Resettlement, which is a comprehensive concept that includes all kinds of residential resettlement activities, refers to a human settlement in the most common and broadest sense. Resettlement policy is on the other hand, directly related to the economic, social and political systems of the states. Therefore, settlement practices are a set of political and spatial arrangements that concern almost all areas of social life.

It is important to ensure the cultural continuity of rural settlements in the planning of stateassisted resettlement projects for rural settlements subjected to forced migration within the scope of development projects carried out in our country. Because it is important for sustainable development to be able to preserve the traditional fabric of rural settlements, which are shaped by traditional land uses and natural environment and have the most distinctive features of cultural landscapes, and to ensure the socio-cultural and economic continuity of rural life. In this sense, evaluating the resettlement projects implemented by the state and revealing the positive and negative aspects will contribute to developing suggestions for future applications. In this study, the Bozkır Barrage Resettlement project planned in Çarıklar Area of Konya province Meram district for Dedemli village of Hadim District of Konya Province, which will be flooded with the start of water collection of Bozkır Barrage, which is constructed in the scope of Konya Plains Project (KOP) - one of the biggest development projects of our country, will be discussed. The project evaluation, which will be dealt with in general settlement decisions, parcel and building scale, is aimed to reveal suggestions for future resettlement applications. 


\section{RESETTLEMENT}

Resettlement is defined as a human settlement in the broadest sense (Halaçoğlu, 2006: 1). The concept of resettlement is defined in the Dictionary of Urban Science Terms (1998: 146) as the action of a social cluster or a large population group to choose a specific place in order to live and maintain their economic activities.

Resettlement is a dynamic phenomenon that has established the social space by growing with the stages of orientation to social life starting with the integration of human, nature and space. The essential purpose of this process is not only settlement, but also a better life effort, civilization and environmental development. This concept including the meanings of the "place", which indicates the moment in history as well as the place in geography, is to start living in that place or to belong there as a result of staying for a long time and gradually becoming "this place" (Bayhan, 1985: 5; Cengizkan, 2004: 13) and giving new qualifications to the "place", is a political choice related to the social laws of the country (İnan Emek, 2014: 84).

The concept of resettlement is defined in Article 17 of the Resettlement Law No. 2510 prepared by Turkey Environment and Urban Ministry General Directorate of Construction Works as "A house or place of residence to live for a family, according to its population and needs, a shop or store or such structure or place that will provide a livelihood for craftsmen and traders, and permanent capital; It is also defined as giving farmers enough soil, couple animals, tools and equipment, seed, barn and hayloft or place". In this definition, the concept of resettlement has been discussed extensively from the concept of settlement, with an emphasis on providing dwelling and housing places to meet the sheltering needs of families and providing opportunities for them to participate in the production process. The concept of resettlement, which is translated into Turkish as "settlement" in the Dictionary of Urban Science Terms (1998: 140) is defined as "the movement of individuals and families who were displaced from their homes to their new settlements, and residing there and providing them with working opportunities". In the aforementioned definition, the concept of resettlement is handled in a similar way to Article 17 of the Resettlement Law No. 2510 (İnan Emek, 2016: 13).

Tekeli (1990: 50-51) and Tercan, (2008: 47-48) classified the resettlement practices according to their purposes as; i. resettlement practices in order to ensure security and order, ii. resettlement practices in line with population policies, and iii. resettlement practices arising from production and development factors. Within the scope of this study, resettlement carried out by the state as a solution to the resettlement problem caused by the development projects developed based on the development of the country will be discussed.

\section{MIGRATION}

In the most general sense, migration or migration movement is defined as "settlement changes between well-defined geographic regions or administrative areas" (Ünalan, 1998: 91). Migration and immigrant movements, which are as old as human history, continue to increase today. The first migrations of history that emerged from the need to find food remain up-to-date in the twenty first century, depending on physical, political, historical, military and socio-economic, cultural and environmental factors (Gürbüz \& Karabulut, 2008: 38; Tümertekin \& Özgüç, 2004: 236; Tanoğlu, 1966: 79).

The definition of migration basically includes distance and time dimensions, and sometimes it can be considered whether the migration movement is permanent or not (Ünalan, 1998: 91-92). However, defining the concept only as a demographic process is insufficient to explain its content and narrowing the meaning of migration (Yenigül, 2005: 274). The concept of migration also fulfills the function of adapting the settlement system to changing conditions (Tekeli, 2011: 163). Migration, which falls within the scope of different scientific disciplines is a process of change that arises from social, political, economic, ecological or individual reasons and needs to be examined both in terms of time, place and purpose. This process is basically a sociological phenomenon in terms of causing different results in the social structure. The phenomenon of migration may be a reason for 
resettlement practices or it may arise as a result of resettlement policy. For this reason, it can be said that the concept of migration lies at the basis of resettlement policy and resettlement practices (Inan Emek, 2016: 15).

Migration movements, as Tuzcu (2008: 10) stated, constitute one of the strongest expression methods of the relationship between human and space. The competence of people in transforming the spaces or the social phenomena they create in a spatial way emerge with the migration process. However, the perception of the concept of migration only as a result of the physical movements of the people, in other words, reducing the phenomenon of migration to spatial mobility will cause many social consequences of migration to be ignored. In this case, instead of defining migration in terms of human and space, there is a need for a scope that includes space, but on the other hand, does not ignore the cultural, economic, social, political and even ecological transformations of migration.

When it is desired to classify the phenomenon of migration according to the power of the main factors affecting migration, it is possible to divide the phenomenon of migration into two groups as voluntary migration and involuntary (forced) migration, taking into account the preference of the individual. Voluntary migration is the displacement from one settlement to another, in line with people's own wishes and expectations. Basically, although it depends on the wishes and preferences of the individual, the place of residence and the social, economic and political conditions in the mentioned place are determinant in these requests and preferences. Involuntary migration can be defined as the displacement that occurs with the effect and strain of various forces against the will of the individual. For example, the mobility in the population as a result of the implementation of the decisions taken by the state on social, economic, security and similar issues constitutes forced migration (Erkan \& Bağlı, 2005: 109, Akkaya, 1979: 23)

\section{Development-induced involuntary (forced) migration: Basic Models}

There are not many models developed to explain the problem of development-induced displacement. There are two basic models in the literature that direct this discipline. The first of these was developed by Scudder and Colson in 1982 and attempted to define resettlement in four stages. These stages are called (1) employment (2) transition (3) economic and social development (4) transfer to local governments and integration (Scudder \& Colson, 1982: 272).

In the late 1990s, Cernea (1998: 42-66) produced a new model called "Impoverishment Risks and Reconstruction". Unlike Scudder \& Colson's model, this model is not concerned with the stages of resettlement, but aims to group the main risks brought about by resettlement. Cernea identified 8 key risks related to displacement and resettlement in this model:

a) Landlessness - loss of land which is the main source of livelihood for many;

b) Joblessness - most people losing their jobs;

c) Homelessness - loss of house or shelter;

d) Marginalization - the inability of displaced persons to maintain their old social networks and standards;

e) Food insecurity - Calorie-protein intake to be far below what is needed for growth and work;

f) Increased morbidity - significant decline in health and even increased mortality;

g) Loss of Access to common property resources - limiting access to common resources such as forest areas, water resources, pastures, graves;

h) Community disarticulation - dissolution of social networks and ties (social organization, interpersonal relationships, kinship groups and other ties) (Cernea, 2000: 19-20).

It can be said that Cernea's model is the most effective model in displacement and resettlement studies. The World Dams Commission has used this model in its work to establish the link between displacement and human rights. In particular, the proposal that dam decisions should be made taking into account the rights of all stakeholders and the risks they will encounter, has brought the discussions about dams to a new dimension. The World Dams Commission has prepared its strategic priorities and guidelines according to this approach (Satıroğlu, 2012: 26). 
Recently, Downing and Garcia-Downing (2009) developed a new theory of the psychosociocultural damage caused by resettlement. According to Downing and Garcia-Downing (2009), there are five fallacies that block discussions and actions within the scope of resettlement: (1) the fallacy that the compensation will be sufficient, (2) the fallacy that the resettlement risks will be solved if the project adheres to the applicable plans, policies and laws, (3) the fallacy that the psycho-sociocultural problems are caused by the displaced persons not being able to benefit from the options offered to them, (4) the fallacy that the project's responsibilities towards individuals will end with the completion of the construction of the new settlement; and (5) the fallacy that the project designers, governments and financiers cannot be held responsible for psycho-socio-cultural changes. Downing and Garcia-Downing (2009) argue that forced migration disrupts the balance of cultures and causes a temporary disharmony in time, space, relationships, norms, and psycho-sociocultural structures. In this theory, forced migration transforms routine culture into a dissonant culture, and then this dissonance turns into a new routine culture. Downing and Garcia-Downing (2009) suggested that resettlement efforts should focus on reducing this social disharmony and enabling the rapid emergence of a new routine culture (Downing \& Garcia-Downing 2009: 238-240).

\section{Types of Compensation Expropriation}

Expropriation is the power of the state to seize property without the consent of a person when the public interests require it. Although expropriation is named differently in different countries, the principle behind it all over the world is the same: the state can seize the property of its citizens when it is dictated by the general good or interest. The expropriation of lands and other real chattels causes frequent displacement of the owners or users (e.g. tenants) of these properties. In large-scale expropriations, such as infrastructure projects, some countries give land against land or resettle the displaced people (Cernea, 2008:49).

\section{Resettlement}

The literature generally criticizes cash compensation and argues that resettlement (also called settlement or land compensation) should be preferred to cash compensation by giving the displaced people houses and/or land. The World Bank (1998) report warns that resettlement and land compensation is extremely difficult and complex and rarely applied correctly, and argues that cash compensation works better and should always be available as an option, especially in entrepreneurial communities. Resettlement can be urban or rural. Settlements are generally based on agricultural land distribution, but may include access to other natural resources (such as forest, wildlife, fish resources) needed by the community to be resettled. Urban resettlement, on the other hand, may include housing in urban or semi-urban centers, job opportunities or financial assistance and loans to restore the livelihoods of the displaced people (Satıroğlu, 2012: 49).

\section{Applications in Turkey}

Although there are so many people in Turkey forced to migrate for the projects required land such as roads, dams, airports, urban transformation, there is no existing study on the numerical dimensions of development-induced forced migration. According to the laws in Turkey, there are two choices for the displaced people as a result of a project like dam or so realized by the state: Taking the expropriation value of the seized properties or being resettled by the state. According to the applications in Turkey; households opting for taking the expropriation value are settled by migrating to places of their choice on their own. Those who are resettled by the state are given home and agricultural land if they prefer rural resettlement, and those who prefer urban resettlement are resettled in houses given from an urban center (the nearest district or city) (Satıroğlu, 2012: 54). 


\section{VILLAGE DESIGN GUIDELINES}

Design guides, which are primarily included in the field of urban design, are defined a set of rules that direct the control of the city and its parts, or contain, guide and shape the design criteria required for the whole city. In other words, it includes conceptual frameworks that especially urban designers, urban planners, municipalities and other city management units have to use in order to discipline the physical spatial changes brought about by urban growth and to direct new designs, urban renewal and conservation studies. The content of design guides can be in different formats and levels of detail. In connection with the feature of being unique to the place, this differentiation occurs spontaneously since every place has different characteristics. However, the preparation process of many design guides is similar, in this process, first of all, relevant policies are presented, principles that will guide these policies are put forward, existing forms and elements that constitute local identity are analyzed. A guide takes care of the overall view of the built environment; it includes planning and design objectives of all scales, including the design of buildings, spaces, landscaping and transportation systems; it is closely related to the authorities, experts and especially the society living there (Eminağaoğlu \& Çevik, 2007: 158).

The "village design guidelines", which is one of the design guides that can be prepared in different dimensions in the field of urban design, originates from the natural environments that we find unique and different, which are the elements that make rural areas special compared to urban areas, the natural landscape with ecological value and the physical structuring suitable for the "place" (Çınar \& Aydın, 2019: 3172) is a document that contains recommendations on how to ensure the continuity of the elements that make up the rural character. The guidelines includes detailed spatial issues such as how to preserve the integrity with the natural environment in the village, how to arrange the common living spaces, how to use the parcels correctly according to the climate and land conditions, how to make the local materials reusable and how to shape the elements such as windows and roofs to adapt to the village. In the countries where the guideline is applied, the local community has an active role in the preparation of the guideline. A guideline adopted by the public is considered to have a high chance of success (Owen, 1998: 42; Owen, 2002: 362-363).

The purpose of the village design guidelines, which have been used as a design policy tool that gives the criteria of local rural building in many countries such as America, Germany and England, is to express the character of settlement created by local differences. In village design guidelines, some criteria are used to define the rural environment and its character: These criteria can be listed as landscape location, physical form of the settlement, structures and natural materials, areas and borders, silhouette and view that help to determine the design principles based on local character. Settlement character, local difference, change, buildings and harmony with the environment, the meaning of the place are important criteria that should be included in the guideline. In the examples abroad, village design guidelines mostly explain the importance of the village in the landscape; a small number of guides are produced that include social opportunities such as migration, health, sports, education, home ownership and economic conditions. Village design guidelines, which are among the most common mechanisms that affect development and are used by local authorities in developed countries, are mostly used as planning tools, besides, there are also those gain legal status over time. The most important common feature of some foreign examples whose content and functioning can be seen in Table 1 is that they all adopt policies to ensure the continuation of the local character and protect the landscape quality (Eminağaoğlu \& Çevik, 2007: 159). 
Büyükşahin, S. (2020). Involuntary (forced) migration in rural settlements and resettlement: Case of Konya - Bozkır Barrage Resettlement. Journal of Human Sciences, 17(4), 1014-1031. doi:10.14687/jhs.v17i4.6071

Table 1. Village Design Guidelines Samples in Foreign Countries (Eminağaoğlu \& Çevik, 2007: 160)

\begin{tabular}{|c|c|c|c|c|c|c|}
\hline $\begin{array}{c}\text { Village Design } \\
\text { Guidelines }\end{array}$ & $\begin{array}{l}\text { Region - } \\
\text { Country }\end{array}$ & Aim & Policies & Content & Legal Frame & Prepared by \\
\hline BELBROOK & Ohio - U.S. & $\begin{array}{l}\text { Preserving } \\
\text { historical } \\
\text { character of } \\
\text { architecture and } \\
\text { building tradition } \\
\text { in the } \\
\text { development of } \\
\text { the village }\end{array}$ & $\begin{array}{l}\text {-deconstruction of a } \\
\text { building or a part of it } \\
\text {-renewing the façade } \\
\text {-new buildings } \\
\text {-landmarks }\end{array}$ & $\begin{array}{l}\text {-introduction } \\
\text {-old village region } \\
\text {-general view } \\
\text {-inappropriate } \\
\text { location } \\
\text {-eliminate } \\
\text {-change } \\
\text {-rebuild }\end{array}$ & $\begin{array}{l}\text { In Zoning Law } \\
\text { Article 14. Updated } \\
\text { according to } \\
\text { developments } \\
\text { (Bellbrook Zoning } \\
\text { Code Article:14) } \\
\text { (Planning tool) }\end{array}$ & $\begin{array}{l}\text { Land owners, } \\
\text { settlement } \\
\text { residents, } \\
\text { architects, } \\
\text { concerned } \\
\text { region } \\
\text { locals, Village } \\
\text { Review } \\
\text { Board }\end{array}$ \\
\hline $\begin{array}{c}\text { MANHATTAN } \\
\text { BEACH }\end{array}$ & $\begin{array}{c}\text { California - } \\
\text { U.S. }\end{array}$ & $\begin{array}{l}\text { Preserving } \\
\text { existing street } \\
\text { views, ensuring } \\
\text { the appropriate } \\
\text { development for } \\
\text { the character of } \\
\text { the region }\end{array}$ & $\begin{array}{l}\text {-preserve little village } \\
\text { character } \\
\text {-preserve, rehabilitate } \\
\text { and reinforce } \\
\text { pedestrian roads } \\
\text {-preserve and } \\
\text { encourage the } \\
\text { comfort of the streets }\end{array}$ & $\begin{array}{l}\text {-region and site } \\
\text { design } \\
\text {-neighborliness } \\
\text { development } \\
\text {-architectural } \\
\text { character } \\
\text {-pedestrian road } \\
\text {-landmarks } \\
\text {-commercial region }\end{array}$ & $\begin{array}{l}\text { Accepted as basic } \\
\text { activities in City } \\
\text { Development Plan } \\
\text { by City Council } \\
\text { (Planning tool) }\end{array}$ & $\begin{array}{l}\text { City Planning } \\
\text { Commission }\end{array}$ \\
\hline $\begin{array}{l}\text { MT. SHASTA } \\
\text { MOUNTAIN }\end{array}$ & $\begin{array}{c}\text { California - } \\
\text { U.S. }\end{array}$ & $\begin{array}{l}\text { Forming an } \\
\text { attractive, } \\
\text { comfortable and } \\
\text { contemporary } \\
\text { village that is in } \\
\text { harmony with } \\
\text { the nature, } \\
\text { reflecting the } \\
\text { historical past of } \\
\text { the local } \\
\text { buildings and } \\
\text { suitable for } \\
\text { mountain } \\
\text { architecture }\end{array}$ & $\begin{array}{l}\text {-preserve the } \\
\text { silhouette character } \\
\text {-visually good looking } \\
\text { environment } \\
\text { dominant footpath } \\
\text { solutions should be } \\
\text { encouraged } \\
\text {-the harmony of } \\
\text { structures with each } \\
\text { other and the natural } \\
\text { environment must be } \\
\text { maintained and } \\
\text { encouraged. }\end{array}$ & $\begin{array}{l}\text {-introduction } \\
\text {-legal frame } \\
\text {-landscape } \\
\text {-buildings and } \\
\text { public spaces } \\
\text {-building and } \\
\text { landscape details }\end{array}$ & $\begin{array}{l}\text { City of Mt. } \\
\text { Shasta's } \\
\text { Architectural } \\
\text { Review Ordinance } \\
\text { Chapter: } 18.60\end{array}$ & $\begin{array}{l}\text { City Planning } \\
\text { Commission }\end{array}$ \\
\hline EAST MEON & $\begin{array}{l}\text { Hampshire } \\
\text { - United } \\
\text { Kingdom }\end{array}$ & $\begin{array}{l}\text { Rehabilitating the } \\
\text { negative views in } \\
\text { the village and } \\
\text { providing the } \\
\text { sustainability of } \\
\text { local character }\end{array}$ & $\begin{array}{l}\text {-preserve green fabric } \\
\text {-consider the effect of } \\
\text { new farm } \\
\text { constructions } \\
\text {-preserve the natural } \\
\text { situation of Meon } \\
\text { River with the valley } \\
\text {-provide the } \\
\text { continuity of the } \\
\text { balance between open } \\
\text { and closed spaces }\end{array}$ & $\begin{array}{l}\text {-introduction } \\
\text {-rural environment } \\
\text {-buildings } \\
\text {-open areas } \\
\text {-village life } \\
\text {-design report } \\
\text {-method } \\
\text {-steering group }\end{array}$ & $\begin{array}{l}\text { Adopted by } \\
\text { Regional } \\
\text { Consultation } \\
\text { Board, Region } \\
\text { Council (EHDC) as } \\
\text { a planning tool and } \\
\text { has been taken to } \\
\text { the annual meeting } \\
\text { agenda }\end{array}$ & $\begin{array}{l}\text { Planning } \\
\text { Group: } \\
\text { President } \\
\text { Treasurer } \\
\text { Secretary } \\
\text { Four party } \\
\text { leaders } \\
\text { Two citizens } \\
\text { Promotion } \\
\text { manager } \\
\text { Two district } \\
\text { councilors }\end{array}$ \\
\hline MANCHESTER & $\begin{array}{l}\text { North } \\
\text { England }\end{array}$ & $\begin{array}{l}\text { Providing the } \\
\text { development and } \\
\text { the sustainability } \\
\text { of the region in } \\
\text { historical } \\
\text { environment }\end{array}$ & $\begin{array}{l}\text {-preserve historical } \\
\text { structure of the village } \\
\text {-preserve historical } \\
\text { small settlement } \\
\text { characteristics } \\
\text {-avoid the building to } \\
\text { harm the historical } \\
\text { view }\end{array}$ & $\begin{array}{l}\text {-introduction } \\
\text {-objectives for the } \\
\text { village } \\
\text {-design control } \\
\text { region } \\
\text {-historical center } \\
\text { region } \\
\text {-historical } \\
\text { conservation region } \\
\text {-general region } \\
\text { view }\end{array}$ & $\begin{array}{l}\text {-Included in } \\
\text { Vermant Land } \\
\text { Use Regulation } \\
\text { (Act.250). } \\
\text {-Updated every five } \\
\text { years. } \\
\text {-Included in } \\
\text { Regulations as } \\
\text { planning tool }\end{array}$ & $\begin{array}{l}\text { Regional } \\
\text { experts }\end{array}$ \\
\hline ROLLESTON & $\begin{array}{l}\text { Staffordshir } \\
\text { e - United } \\
\text { Kingdom }\end{array}$ & $\begin{array}{l}\text { Revealing the } \\
\text { history of the } \\
\text { region, local life } \\
\text { and environment } \\
\text { in development } \\
\text { process }\end{array}$ & $\begin{array}{l}\text {-guide to form } \\
\text { contemporary } \\
\text { environments suitable } \\
\text { for local character }\end{array}$ & $\begin{array}{l}\text {-introduction } \\
\text {-society, economy, } \\
\text { environment, } \\
\text { settlement, } \\
\text { communication, } \\
\text { developments } \\
\text {-street furniture } \\
\text {-landmarks and } \\
\text { guidelines } \\
\text {-map } \\
\text {-conclusion }\end{array}$ & $\begin{array}{l}\text { Accepted as a } \\
\text { supplementary } \\
\text { planning guideline } \\
\text { (SPG) in East } \\
\text { Staffordshire } \\
\text { District Council } \\
\text { Local Plan }\end{array}$ & $\begin{array}{l}\text {-Rural } \\
\text { Environment } \\
\text { Commission } \\
\text { - Rolleston } \\
\text { Region } \\
\text { Council } \\
\text { - Rolleston } \\
\text { Methodist } \\
\text { Church } \\
\text { - Village } \\
\text { People }\end{array}$ \\
\hline
\end{tabular}


Rural landscapes, where villages are considered as the largest settlement units in our country (Official Gazette 1924), were addressed in 1924 with the Village Law No. 442. In the 2000s, with the studies of the Ministry of Public Works and Settlement, village settlement plans and building projects in accordance with the natural and cultural structure and local architecture were developed. Finally, with the Law No. 6360 (Official Gazette 2012) on the Establishment of Metropolitan Municipalities and Twenty-Seven Districts in Fourteen Provinces and Amendments to Certain Laws and Decree Laws, zoning practices for rural areas, especially rural settlements, brought the Village Design Guidelines to the agenda. Within the scope of the law, the zoning practices of the municipalities will be valid for the villages converted into neighborhoods by expanding the metropolitan municipality boundaries to the provincial border. According to this law, the legal personality of the villages has been removed and transformed into neighborhoods, and if the district municipalities or district municipalities request, metropolitan municipalities will be in a position to make or have architectural projects suitable for the traditional, cultural and architectural characteristics of the region in line with the current zoning legislation for non-commercial buildings. The relevant district municipality will be authorized in determining the area boundary. The fact that urban fabric and building density will be transferred to rural areas with these development applications has made Village Design Guidelines with rural landscape character a need for our country (Balta \& Atik, 2019:2).

Village Design Guidelines studies in Anatolia first started with the example of Kastamonu Küre Ersizlerdere Village Design Guide (2015), and continued with Küre Mountains National Park Bartın Section Villages (Görmiş et al., 2015); Erdek, Yukarıyapıcı (Öğdül et al., 2018) and Ödemiş Bademli (Görgün\&Yörür, 2018); Denizli Merkezefendi and Pamukkale districts (Özdemir, 2015). Kaş, Bezirgan Village Design Report studies are still ongoing (Antalya Metropolitan Municipality, 2015). When these studies are examined, the village design guidelines in our country mostly focus on the structural features and architecture of the villages with the perspective of architecture and city and regional planning disciplines. On the other hand, Village Design Guidelines are based on multiple criteria on settlement, building, plot and garden characteristics, cultural values. Village design guidelines developed in this sense should be considered to be applicable in the settlement areas to be planned in their new locations for the villages that have been moved by the state because of forced migration or many other reasons, as well as contributing to the development of existing villages.

\section{THE CASE OF KONYA BOZKIR BARRAGE RESETTLEMENT}

A resettlement project is realized by the state for the residents of Dedemli village in Hadim district of Konya province which will be flooded when the Bozkır Barrage starts to hold water. Bozkır Barrage is constructed as a part of the Konya-Çumra $3^{\text {rd }}$ Stage Project in the scope of Konya Plains Project (KOP) which is the first irrigation project in Turkey and second biggest development project after Southeast Anatolia Project (GAP). Within the scope of the investigation of Konya Bozkır Dam Resettlement Project, which was determined as the case study, general information about Hadim district in Konya province and Dedemli village will be given, and then the project will be discussed in detail.

\section{Hadim district and its history}

Hadim is a small town of Konya established in a valley in the center of the Central Taurus Mountains. There are Karaman province in the east, Taşkent district in the south, Bozkır in the north and west, and Alanya district in the southwest. The district center is $130 \mathrm{~km}$ from Konya and its altitude is 1500-1700 meters. (Sak, 1997: 169). Hadim district was founded on narrow valleys between the hills of the Taşeli Plateau in the eastern region of the Western Taurus Mountain range that separates the Mediterranean coastline and the Konya Plain (Duran, 2019: 8).

Hadim founded in ancient times is located in the Isauria region, near the ancient city of Astra, lived in the Hittite, Roman, Byzantine, Seljuk, Karamanoğulları and Ottoman periods and always showed the character of a village until the 18th century. After this date, Ebu Sâid Muhammed Hâdimî and his family established a madrasah and enabled the district to develop in the field of science and 
culture. Establishing a library in the district was a wealth that many small settlements could not have in those times. Hadim could not show this development in the field of science and culture in the 18th and 19th centuries in other fields. The most important reason for this is that the transportation of this settlement in the Taurus Mountains is problematic (Kara, 2006: 109).

The history of Hadim and its surroundings, which is located within the borders of the Klikya region (Ertan, 1974: 93), goes back to the first ages. There are many settlements belonging to the Greek and Roman periods in the region called Isaura in ancient times (Bahar, 1996: 51). The region was under the domination of Rome since 129 BC (Yllmaz, 1990: 6) and Byzantine in AD 395 (Y1lmaz, 1990: 10, Anonymous, 1998: 25). After the 1071 Malazgirt victory, Hâdim came under Seljuk rule and approximately two centuries later it was captured by the Karamanids. In 1473, as a result of the elimination of Karamanids by Fatih Sultan Mehmet, Hadim was included in the borders of the Ottoman Empire. The first records we have about the Hadim belonging to the Ottoman period were in 1501, the time of II. Bayezid. At that time, Hadim was a village of Aladag district of Konya sanjak (Turan, 1984: 54-55).

Hadim remained as a small village until the era of Abu Said Muhammad Hadimî. However, with the Hadimî, it started to grow and its reputation spread to the Ottoman country. Hadim became one of the science and knowledge centers of the region during the time of Hadimî. While Hadim is mentioned in Ottoman sources, the fact that Hadim is counted among the cities that raised great ulema such as Istanbul, Bursa, Konya and Kayseri shows the importance of the district in that period. Hadim became a district and sub-district center several times in the administrative division made on subsequent dates. Hadim, which was attached to Karaman as a sub-district in 1901, became the district center after May 30, 1926. It is still a district of Konya province (Konya İl Yillığı, 1967,130132).

\section{Dedemli village}

Dedemli village is located 17 kilometers to the northwest of Hadim district center. It is a neighborhood with a population of 2100 in approximately 500 households. Among the main livelihood agricultural products, cherries, pears, apples and grapes are the most grown products. Bovine and ovine breeding are made enough to provide for the people of the region (Kara, 2006:34). There are also live trout facilities. Hadim's Dedemli village is one of the only settlements in the district that has fishing activities. Around $150000 \mathrm{~kg}$ of fish are produced in the town where there are 2 official enterprises. The fish produced are sold to surrounding towns (Yilmaz, 2007: 72).

The foundation of Dedemli dates back to the Seljuk period with the arrival of Seyyid Bayram Veli from Khorasan. The founder of this charming town is Seyyid Bayram Veli, such as Ahmet Yesevi dervishes, Mevlânâ, Hacı Bektâş-1 Veli, who are the principal and sublime architects of Anatolia. He migrated from Khorasan, one of the important science centers of that period, to Anatolia to open Islam to education and development. According to rumors, Sayyid Bayram Veli saw these places in his dream while he was still in Khorasan and, in the love and excitement of his mission, he ended the last stop of a long journey on this slope of the Taurus Mountains. The name of the settlement, formerly known as Bademli, was changed to Dedemli in 1967 (Kara, 2006: 35). 
Büyükşahin, S. (2020). Involuntary (forced) migration in rural settlements and resettlement: Case of Konya - Bozkır Barrage Resettlement. Journal of Human Sciences, 17(4), 1014-1031. doi:10.14687/jhs.v17i4.6071

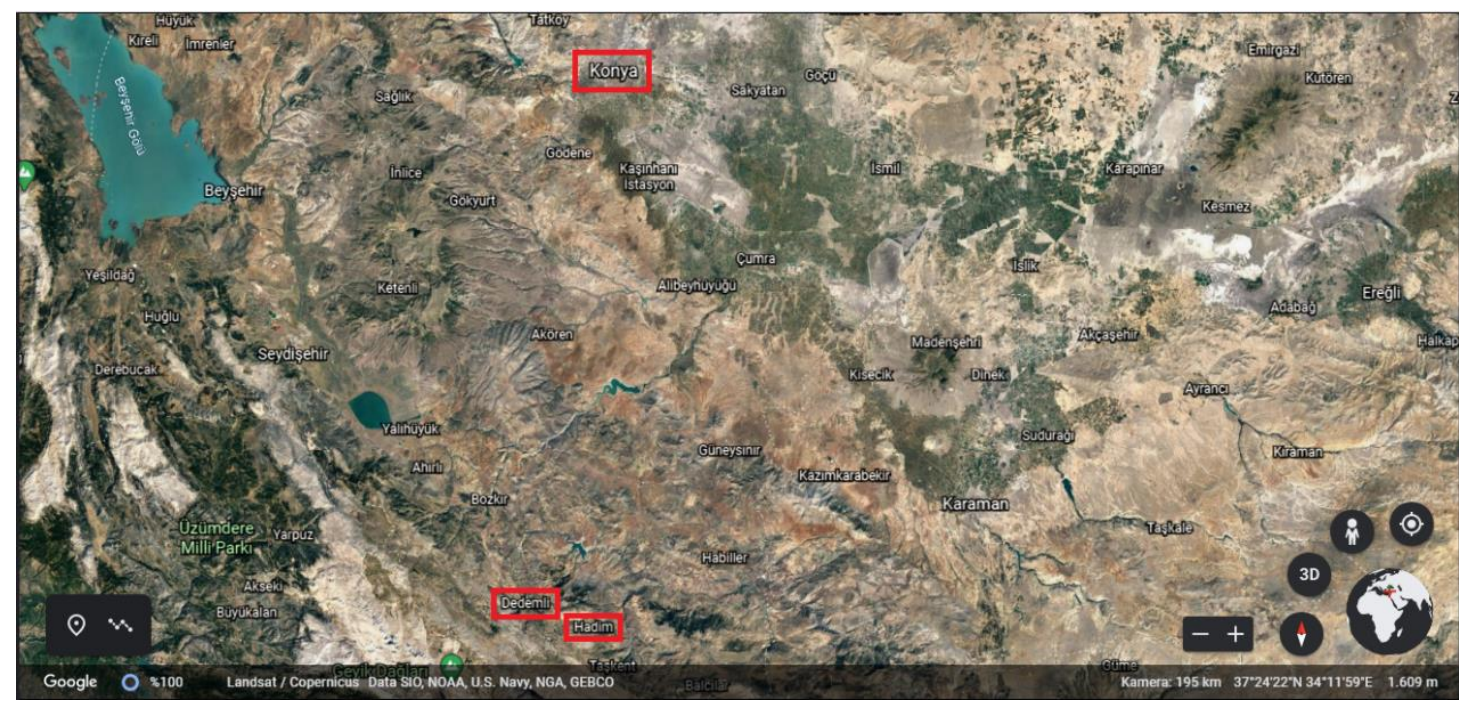

Figure 1. Konya Province- Hadim district- Dedemli village locational relation (google earth, 2020)
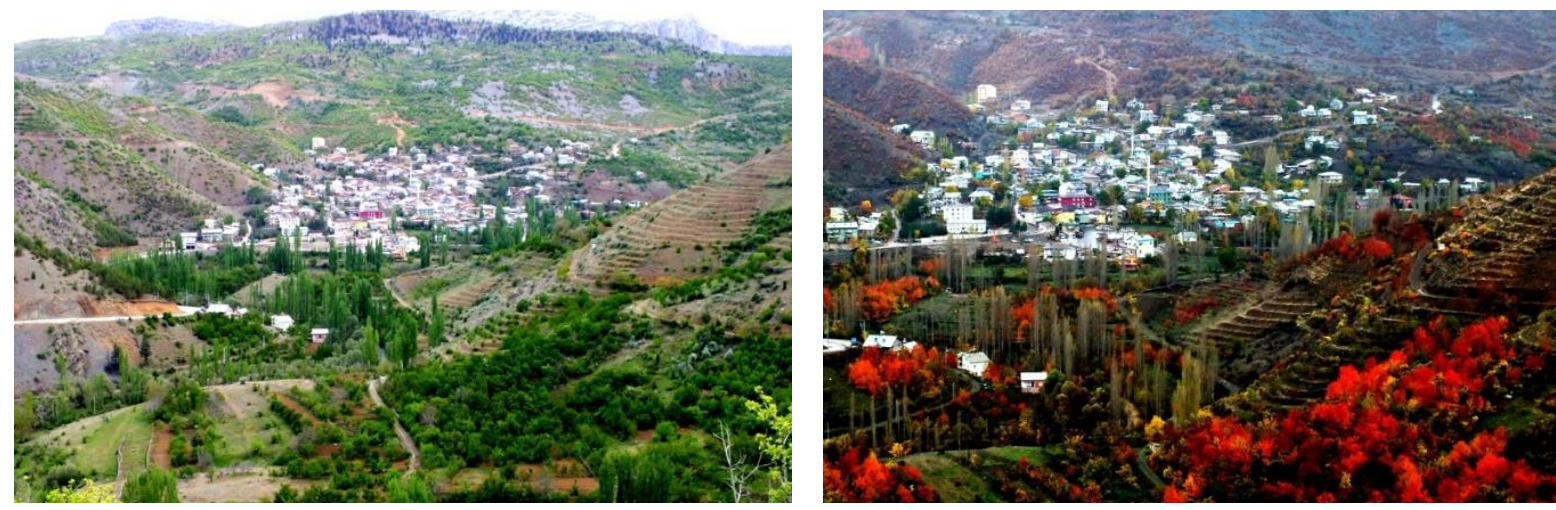

Figure 2. Dedemli Village general views (WEB-8)

\section{Konya Bozkır Barrage Resettlement Project}

Within the scope of Konya Plain Project (KOP), the tender of Bozkır Barrage - one of the projects developed to transfer water from different reservoirs to the Konya Closed Reservoir and to benefit from energy, irrigation and drinking water in this process (WEB1) was held on 24 March 2011 and the foundation was laid on 25 May 2012 (WEB2), construction was completed on May 15, 2017 (WEB3). The diversion tunnel entrance of the Bozkır Barrage, which has a height of 116 meters from the foundation and a water holding capacity of 361 million cubic meters, was closed on 27 August 2020 and the dam started to hold water (WEB1). The new settlement area for Dedemli village - located in the reservoir area of the Bozkır Barrage built by the General Directorate of State Hydraulic Works of the Ministry of Agriculture and Forestry (Figure 3) and will be flooded - was planned in Çarkklar area of Konya province Meram District (Figure 4), the procedures and principles regarding the transfer to the new residential areas, right ownership and debt have entered into force on 06.04.2016 (WEB4). Residence and business buildings were planned for 428 beneficiaries determined as a result of the applications, and 18 workplaces were planned to be built for 18 families engaged in trade. In addition, it has been committed to construct a mosque, fountain, medical center, 2 schools (primary and secondary education), drinking water network, sewerage and roads for the needs of families in the new settlement (WEB5). The "Konya Bozkır Barrage Resettlement Construction" tender was carried out by the General Directorate of Construction Works (YIGM) on December 31, 2018 (WEB6), and the tender with the project start and end dates as 15.02.2019 05.03.2021 was announced on 26.2.2019 (WEB7). 
Büyükşahin, S. (2020). Involuntary (forced) migration in rural settlements and resettlement: Case of Konya - Bozkır Barrage Resettlement. Journal of Human Sciences, 17(4), 1014-1031. doi:10.14687/jhs.v17i4.6071

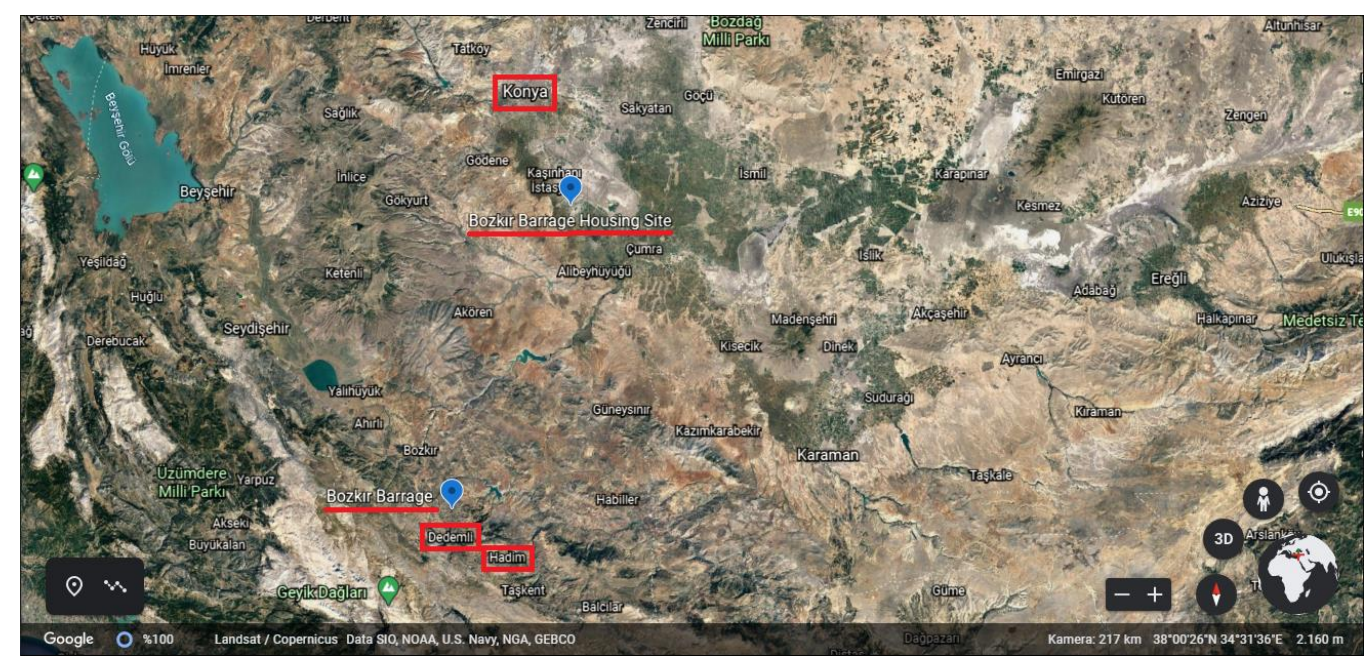

Figure 3. The locational relation of Bozkır Barrage and Bozkır Barrage Resettlement Site (google earth, 2020)

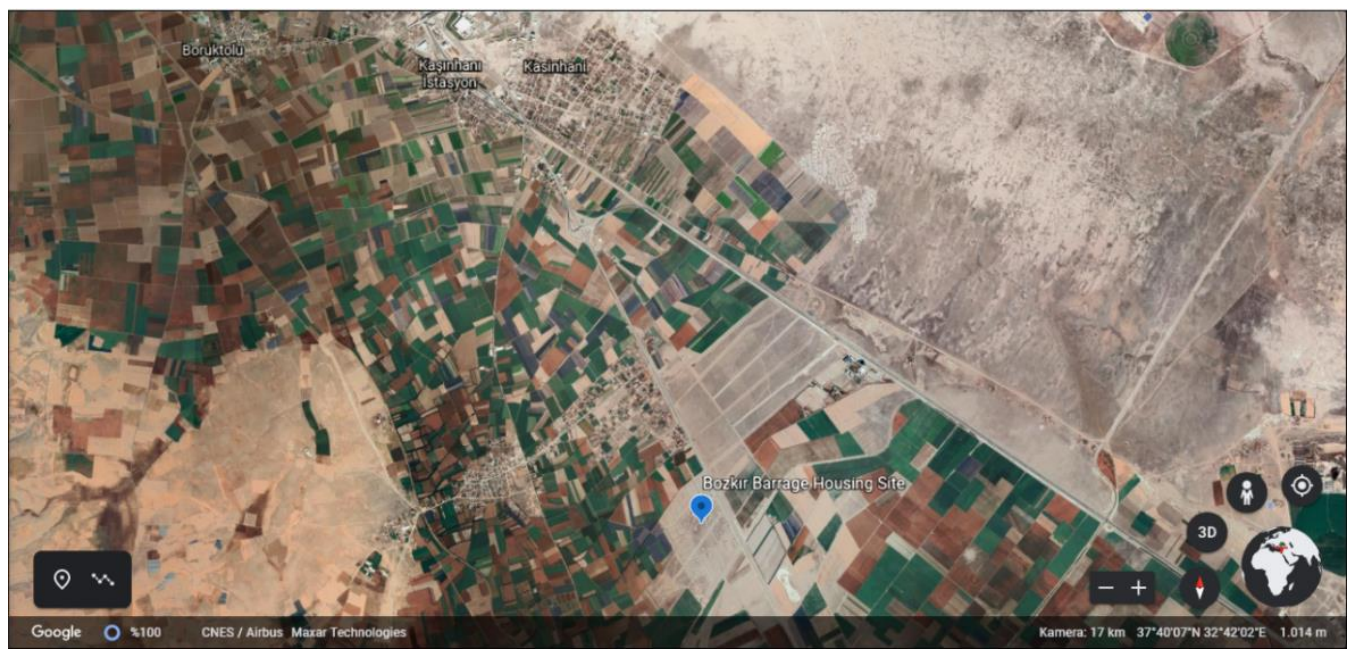

Figure 4. The location of Bozkır Barrage Resettlement Site (google earth, 2020)

When the settlement characteristics of the Dedemli village are examined, it is possible to say that it has characteristics of Central Anatolia rural settlements (Figure 5). In general, in the rural settlements of Central Anatolia, an organic settlement is observed where the population is concentrated on the foothills of the mountains close to the neighboring regions with more rain and water resources depending on the natural conditions of the region, the road layout and hierarchy is shaped according to the topographic characteristics, and the roads formed by the aligned house groups lead to first to the collector roads and then to the main roads leading to the city. It is possible to read a homogeneous fabric created by the buildings constructed with local materials in harmony with the topography on the sloping land in the Dedemli village, which is a valley settlement (Figure 7). When the location chosen for the Bozkır Barrage Resettlement project and the settlement characteristics applied in the project are examined; a gridal settlement layout is read on a wide land located on a flat plain in complete contrast with the Dedemli village, in a region that has completely differentiated from Dedemli neighborhood in meaning of climate, topography, natural resources, vegetation etc. (Figure 6). These differences will directly affect the social and economic life of the villagers, for example there will be no fishing activities in the new location. Therefore the loss of one of the basic way of living for the villagers may cause identity problems such as psychological trauma. A dull and monotonous appearance draws attention in the settlement created by repeating the same residential units produced via a typical project located on the parcels lined up on both sides of the roads created with a grid system. (Figure 8-9). 
Büyükşahin, S. (2020). Involuntary (forced) migration in rural settlements and resettlement: Case of Konya - Bozkır Barrage Resettlement. Journal of Human Sciences, 17(4), 1014-1031. doi:10.14687/jhs.v17i4.6071

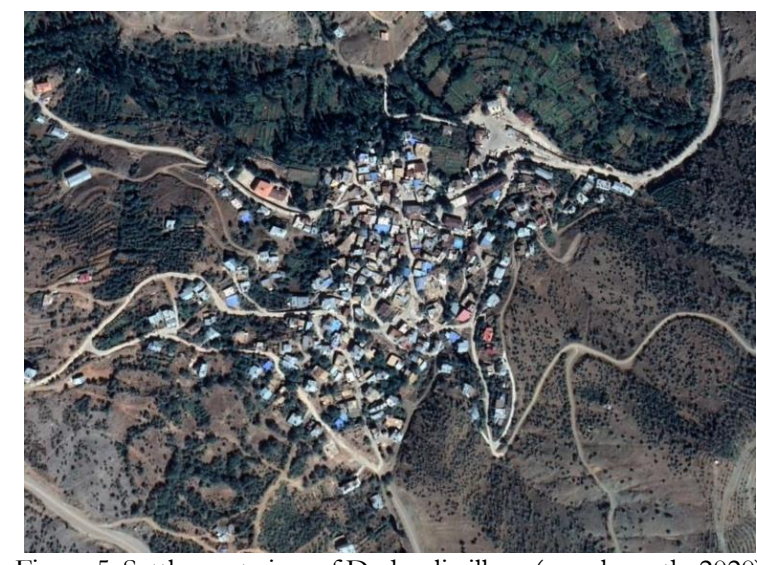

Figure 5. Settlement view of Dedemli village (google earth, 2020)

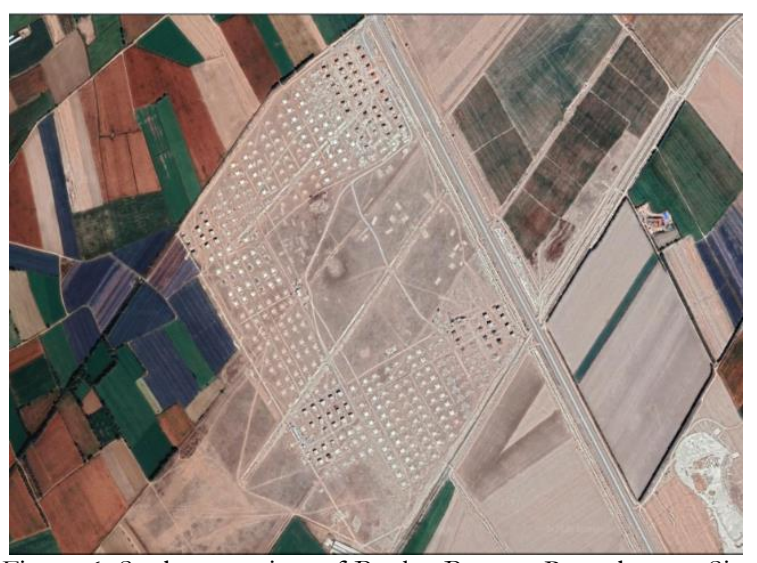

Figure 6. Settlement view of Bozkır Barrage Resettlement Site (google earth, 2020)

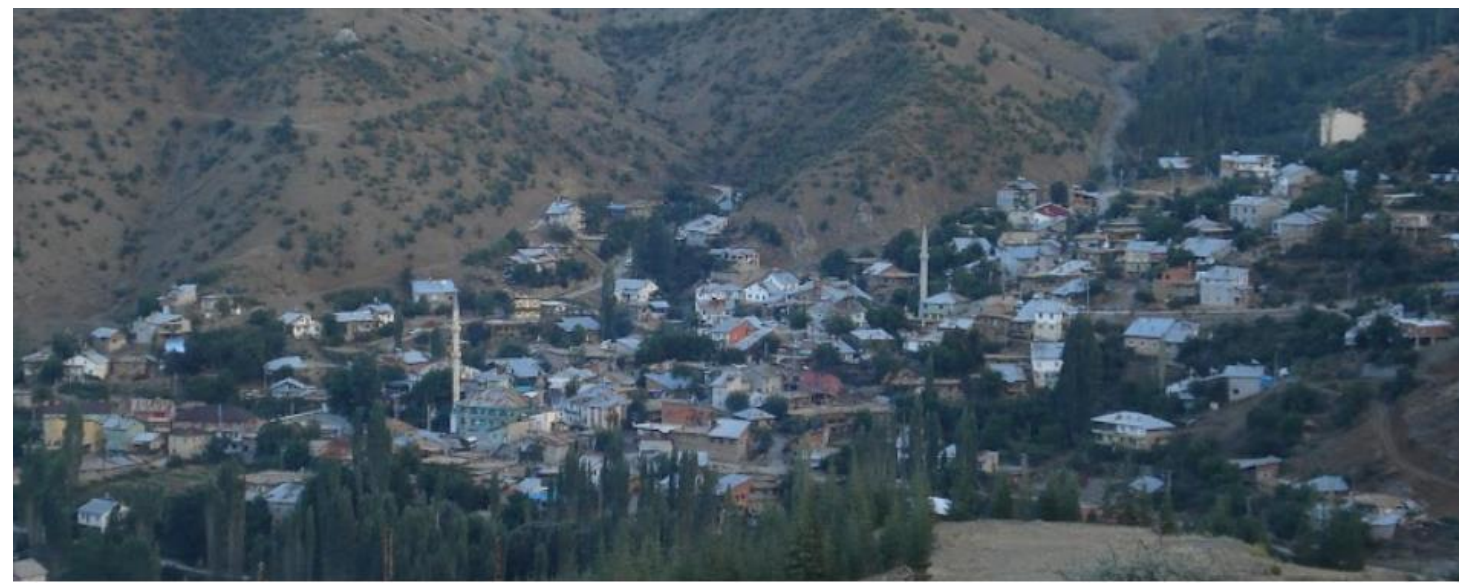

Figure 7. General view of Dedemli District (google earth, 2020)

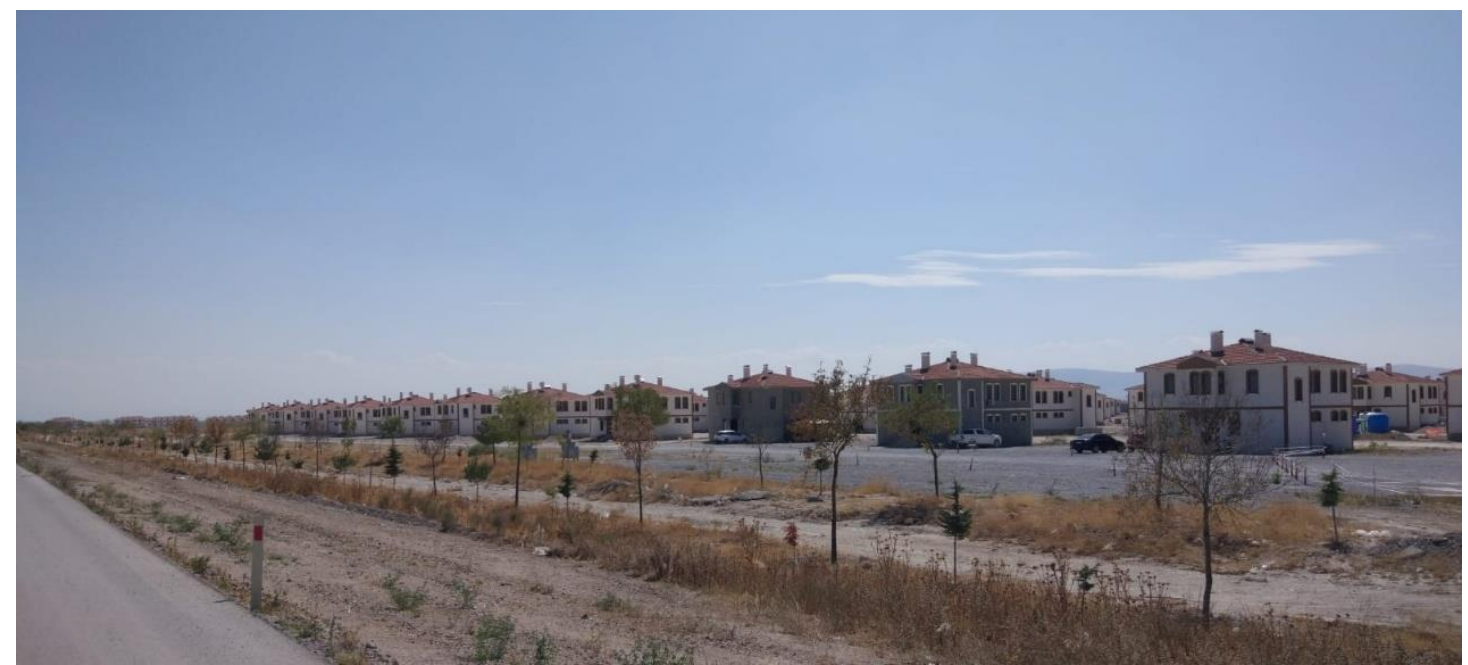

Figure 8.General view of Bozkır Barrage Resettlement Site (Süheyla Büyükşahin’s personal archive, August 2020) 

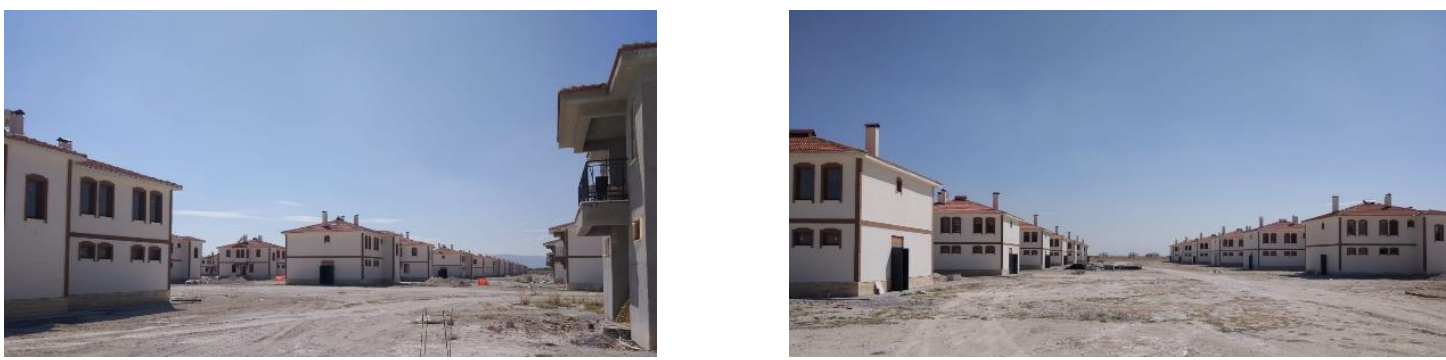

Figure 9. General views inside the construction site of Bozkır Barrage Resettlement Project (Süheyla Büyükşahin's personal archive, August 2020)

When the architectural project prepared by Konya Provincial Directorate of Environment and Urbanization under the name of "Konya Bozkır Barrage Resettlement-Agricultural ResettlementTypical Resettlement Housing Architectural Project" is examined, a parallelogram-like land form adjacent to Konya-Karaman highway on east side is seen. It is read that the urban components other than dwellings of the settlement are planned in a square-shaped area surrounded by houses on three sides and Konya-Karaman highway on east side in a different order from the gridal order adopted in the residential area around the square in the middle (Figure $10 \mathrm{a}-\mathrm{b}$ ). The empty area divided into parcels in the southeast corner of the site is left as a reserve area. When the site plan is examined in general terms, it is possible to say that it does not reflect an architectural integrity in terms of urban planning, that there are identical roads between residential units which are undefined and unidentified in architectural and urban sense. Also the planning of urban components and housing settlement are far from reflecting a compact and integrated structure and reveals long walking distances in difficult climatic conditions of the region.

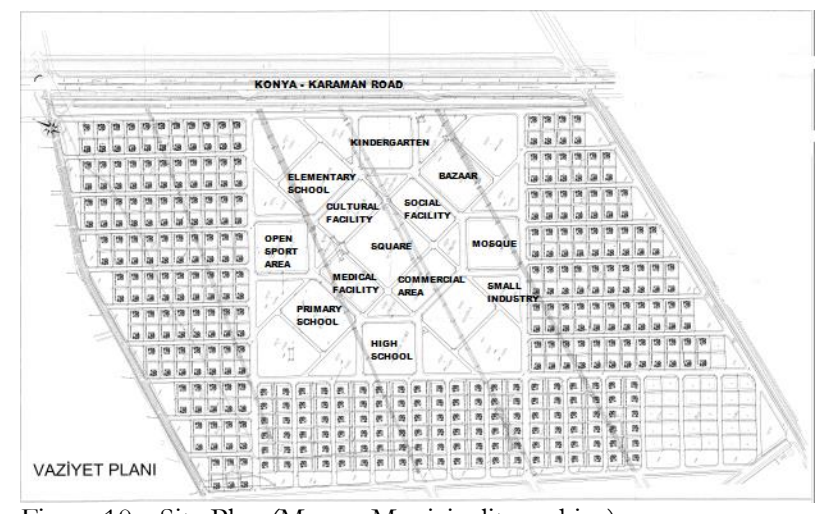

Figure 10.a-Site Plan (Meram Municipality archive)

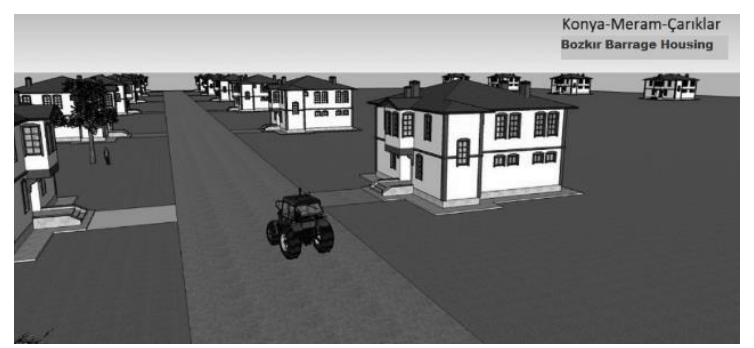

Figure 10.b-Project view (WEB9)

When the house architecture, which is expressed to be inspired from the traditional Konya house and prepared with the typical project, is examined, it is seen that the entrance is provided from the basement level of $50 \mathrm{~cm}$ by the road on the ground floor. On the ground floor, there is only a staircase in the windbreak section that provides access to the upper floor, a warehouse and a thermal center accessed from the warehouse section. The warehouse section is located at the road and garden level and is reached by the staircase opposite the entrance. The warehouse has been directly connected to the garden, and its intended use is left to the user (Figure 11). When the first floor plan, which is planned in the Turkish house with inner sofa plan typology, where the living spaces are located, is examined, it is seen that the rooms are opened through a sofa that is accessed by a staircase. The cantilever created to the right of the stairs functions as an eaves on top of the entrance, there is a kitchen opposite to the staircase, a lavatory (washbasin + toilet), a living room and a room. Even though it is not separated by a door or a divider, 2 rooms and a bathroom are accessed from the area defined as the night hall. (Figure 12). An attempt was made to bring dynamism to the façade with a balcony in the living room and a cantilever above the entrance, the window surfaces in ground floor 
Büyükșahin, S. (2020). Involuntary (forced) migration in rural settlements and resettlement: Case of Konya - Bozkır Barrage Resettlement. Journal of Human Sciences, 17(4), 1014-1031. doi:10.14687/jhs.v17i4.6071

were chosen small because there would be used as a warehouse, and the rear facade was left completely empty except for the ventilation window of the bathroom on the upper floor (Figure13).

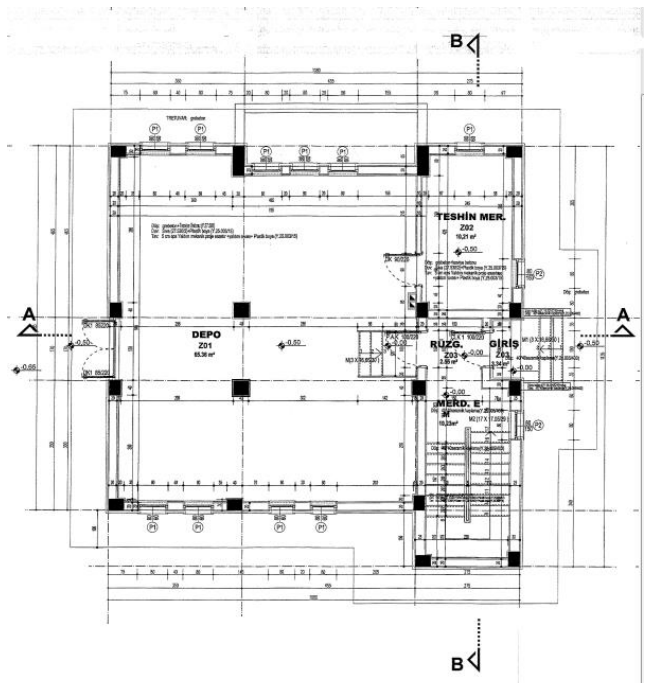

Figure 11. Ground floor plan (Meram Municipality archive)

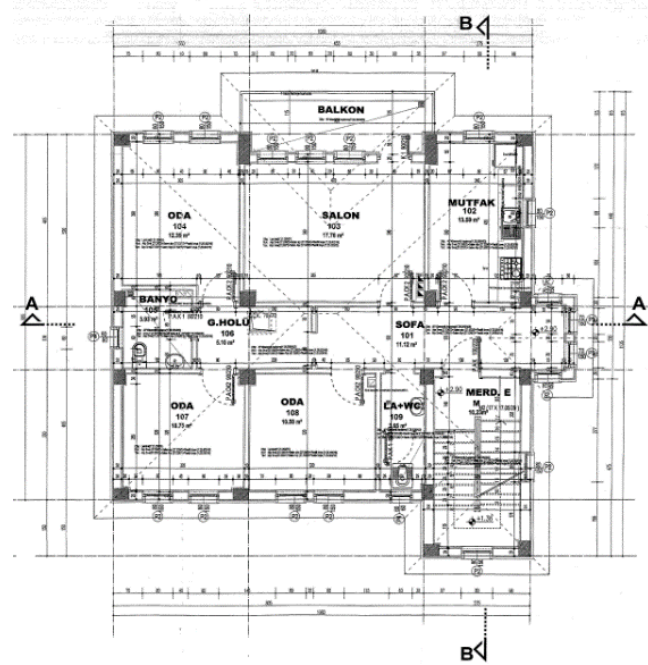

Figure 12. First floor plan (Meram Municipality archive)

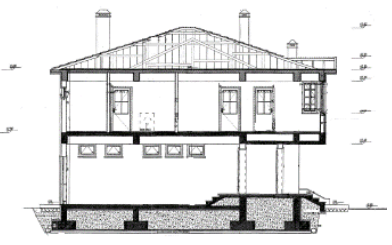

A-A Section

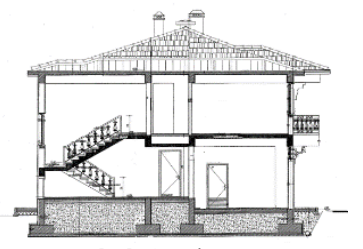

B-B Section

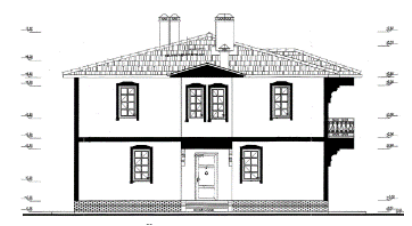

Front facade

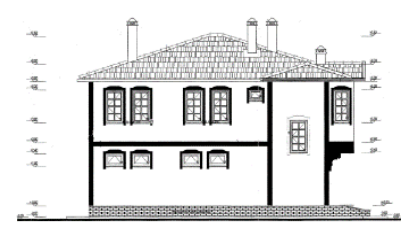

Left side facade

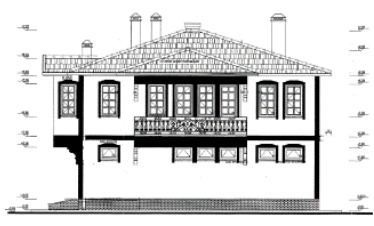

Right side facade

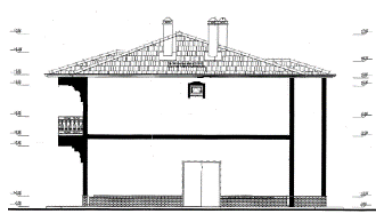

Rare facade

Figure 13. Sections and elevations (Meram Municipality archive)

Traditional Konya houses, which define a daily life intimate with the garden, have two plan typologies with "hayat" and "sofa", and living spaces in both typologies are directly linked to the garden level (Arat, 2018: 78-79). In Bozkır Barrage resettlement project; the fact that the living spaces and the kitchen were taken apart from the garden level and planned on the first floor does not support the way of life of the people who will live here. It is possible to foresee that the villagers, who carry out all their work between the house and the garden during the day, will choose to arrange the ground floor spaces in accordance with their needs in order to adapt to living in this housing typology, and if necessary, they will have to re-create storage, barn, etc. areas in their gardens. When the facade layout is evaluated, although the cantilevers, window proportions, buttresses and traditional facade style have been tried to be reflected, the facade layout on the ground floor and the lavatory window openings on the upper floors have negatively affected the architectural integrity of the facade (Figure

\footnotetext{
${ }^{2}$ Houses with "hayat" are one of the small-scale housing groups that contain the most characteristic features of Konya Houses. The house is entered by passing the forecourt called "hayat" - the front garden covered with stones - from the street. The "hayat" section, with its structure separated from the street by high walls, has made it possible to spend time outdoors with various trees and pool elements, especially in summer, in terms of forming the front garden of the house. The most important feature of homes with "hayat" is that the rooms are lined up next to each other and opened directly to "hayat" (Arat, 2018: 79).

3 The difference between the houses with "hayat" and the ones with "sofa" - which appeals to the extended family and the rich upper class, and which are generally built in large vineyards or gardens - is that the transition to the rooms is through the main place called "sofa" accessed directly from the garden. These houses are symmetrical on plan basis and formed by the transformation of "mabeyn" in houses with "hayat" into "sofa" that extend along the building in the direction of the entrance (Büyükşahin Sıramkaya, 2018: 4523).
} 
14). Based on on-site examinations it is possible to mention that, the houses built with modern building materials in the exterior and interior exhibit a typology far from the traditional architectural typology (Figure 15) and the cultural continuity belonged to the place cannot be achieved.

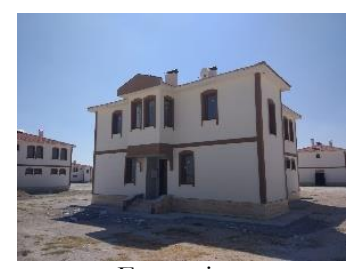

Front view

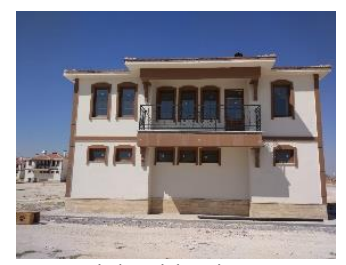

Right side view

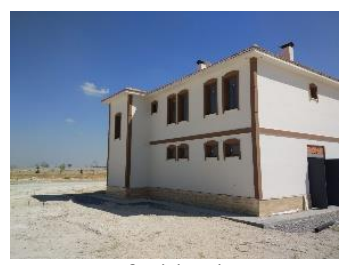

Left side view

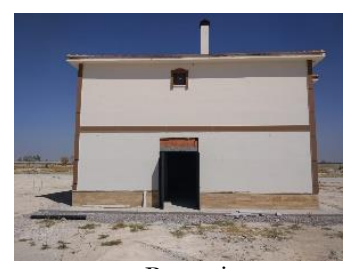

Rare view

Figure 14. Outer views of the dwellings in Bozkır Barrage Resettlement project (Süheyla Büyükşahin’s personal archive,August 2020)

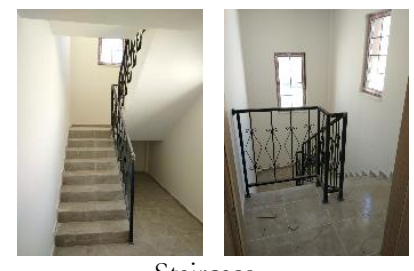

Staircase

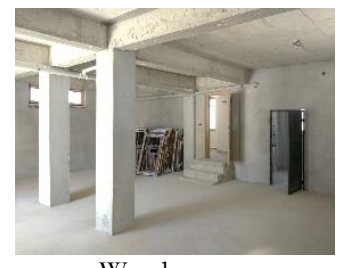

Warehouse

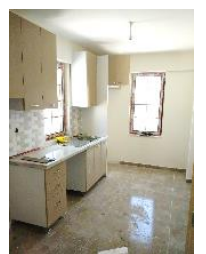

Kitchen

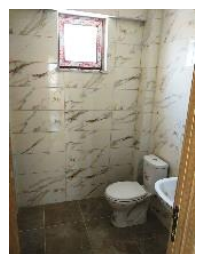

Bathroom

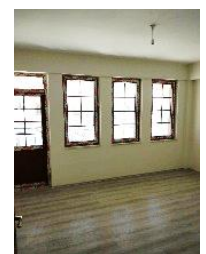

Living room

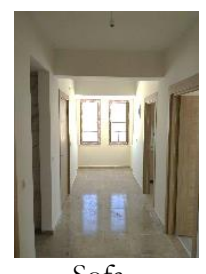

Sofa

Figure 15. Inside views of dwellings in Bozkır Barrage Resettlement project (Süheyla Büyükşahin's personal archive, August 2020)

\section{CONCLUSION AND RECOMMENDATIONS}

The needs such as transportation, water and electricity brought about by the increasing population, changing living conditions and globalization bring along large-scale infrastructure and development projects. Projects such as roads, dams, factories, and mines built to meet these needs directly or indirectly affect both the environment and societies, and often change them irreversibly. Rural settlements - that are heavily affected by the development projects planned throughout the country - are the environments where community architecture is seen, reflecting the physical conditions of the region they live in, the cultural structure and the lifestyle of the period they belong to. Despite the dull structuring of cities that are more and more similar today; rural settlements shaped by the physical environment and their unique lifestyle differ from region to region, even from village to village, within the cultural variety of Anatolian society. The settlements are shaped by the topographical structure, cultural and physical environmental conditions. Generally, experience-based construction and settlement principles bring correct results and high quality landscape and architectural products are obtained. Ensuring the cultural continuity of these settlements is important for the architectural identity of our living spaces.

Since they will be adversely affected by the planned development projects in our country, face the involuntary (forced) migration and resettled by the government, ensuring the continuity of the life styles, spatial, socio-economic and cultural needs of the people living in rural settlements, emerges as an important design problem. In this sense, in order to sustain the existing character and fabric of rural settlements, village design principles with rural landscape character should be established. According to the information in the literature, studies on the conservation of the original character of rural landscapes, which are known to have firstly started in England, are prepared under the name of Village Design Guidelines that aim to design rural areas, protect and develop rural landscapes in many countries and are used as an important physical plan base.

Although some physical regulation principles are determined within the framework of laws in planning studies covering rural settlements in our country, this is very general and insufficient. Rural settlements should be evaluated within a regional scale, "village design guidelines" containing general standards and guiding information within the scope of design policies that will direct the construction should be prepared and they should be applicable not only to villages to be newly 
planned but also to rural settlements that have to be relocated. Rural settlements, as settlements that still preserve their localness in many regions today; contains richness of form, regional materials and examples with rational solutions suitable for local conditions. Village design guidelines are important for the conservation of these examples and their transfer to future generations, in short for the continuity of the culture. Based on the results obtained from this study, it has been revealed that the urban and architectural design institutions in our country should work in a more integrated manner and follow the current researches in the literature. It will not be possible to talk about the continuity of the socio-cultural and architectural identity special to the place unless the logic of the typical project understanding is taken away from the planning principles ranging from rural to urban scale.

\section{REFERENCES}

Akkaya, T. (1979). Göç ve Değişme. İstanbul: İstanbul Üniversitesi Fen Edebiyat Fakültesi Yayınları, Yayin no: 2573.

Anonymous, (1998). Cumhuriyet'in 75. Ylinda Konya. Konya.

Antalya Metropolitan Municipality, (2015). Bezirgan Village Design Guide Studies- Analysis, Antalya Metropolitan Municipality Development and Urban Planning Department, Antalya.

Arat, Y. (2018). A Lost Cultural Heritage: Saim Sakaoğlu House/Konya. Milli Folklor International and Quarterly Journal of Cultural Studies, 30(118):77-100.

Balta, S. \& Atik, M. (2019). The role of rural landscape characters in the preparation of village design statements: the case study of Elmal1, Antalya, Mediterranean Agricultural Sciences, 32(1): 1-9

Bahar, H. (1996). Isauria Bölgesi’nin Antik Çağdaki Yerleşim Merkezleri. Anadolu Araștırmalarn XIV, Prof. Dr. Afif Erzen'e Armağan (Ayrı Basım), s.51-91, İstanbul.

Bakan, G. (2008). Türkiye'de Çevresel Etki değerlendirme (ÇED) Uygulamalarına Çarpıcı Bir Örnek: Samsun Mobil (Termik) Santralleri. Türk Mühendis ve Mimar Odalar (TMMOB) Birliği Samsun Kent Sempozyumu. Samsun: TMMOB.

Bayhan, İ. (1985). Yerleşme Süreci-Şehir ve Şehirleşme, Yıldız Teknik Üniversitesi Şehir ve Bölge Planlama Bölümü Yayımlanmış Ders Notları. İstanbul: Yıldız Teknik Üniversitesi Matbaası.

Büyükşahin Sıramkaya, S. (2018). Syntactic Analysis of Traditional Konya Houses belonged to Late Ottoman Period, International Social Sciences Studies Journal, 4(23): 4520-4533.

Cernea, M. (1998). Impoverishment or Social Justice? A Model for Planning Resettlement. H. M. Mathur, \& D. Marsden içinde, Development Projects and Impoverishment Riskes: Resettling ProjectAffected People in India. Delhi: Oxford University Press.

Cernea, M. M. (2000). Risks, safeguards, and reconstruction: a model for population displacement and resettlemLent. M. M. Cernea, \& C. McDowell içinde, Risks and Reconstruction Experiences of Resettlers and Refugees (11-55). Washington: The World Bank

Cernea, M. M. (2008). Compensation and Investment in Resettlement: Theory, Practice, Pitfalls, and Needed Policy Reform. M. M. Cernea, \& H. M. Mathur içinde, Can Compensation Prevent Impoverishment? Reforming Resettlement through Investments and Benefit-Sharing (15-82). Oxford: Oxford University Press.

Cengizkan, A. (2004). Mübadele Konut ve Yerleşimleri -Çağa Yerleşmek 1-. Ankara: Arkadaş Yayıncilik

Çınar, H. \& Aydın, D. (2019). Comparison of Natural and Socio-Cultural Factors in the Formation of Space in a Moving Village in Anatolia: Old and New Kesmez Village. Turkish Studies, 11 (6): 3167-3186.

Dictionary of Urban Science Terms. (1998). Ankara: İmge Kitapevi. 

Barrage Resettlement. Journal of Human Sciences, 17(4), 1014-1031. doi:10.14687/jhs.v17i4.6071

Downing, T. E., \& Garcia-Downing, C. (2009). Routine and Dissonant Cultures: A Theory about the Psycho-socio-cultural Disruptions of Involuntary Displacement and Ways to Mitigate Them without Inflicting Even More Damage. A. Oliver-Smith in, Development and Dispossession: The Crisis of Forced Displacement and Resettlement (224-254). Santa Fe: School for Advanced Research Press

Duran, K. (2019). The dialect of villages of Hadim (Konya). Master Thesis. Selçuk University Institute of Social Sciences, Department of Turkish Language and Literature, Konya.

Eminağaoğlu, Z. \& Çevik, S. (2007). Design Policies and Means Related to Rural Settlements. Journal of the Faculty of Engineering and Architecture of Gari University. Volume 22, (1):157-162

Erkan, R. \& Bağlı, M. (2005). Göç ve Yoksulluk Alanlanında Kentle Bütünleşme Eğilimi: Diyarbakır Örneği. Hacettepe University Journal of Faculty of Letters (HUJFL), 22(1), s.105-124.

Ertan, F. \& Ertuğrul, V.- Özbaba, R.\& Şengüden, A. (1974). Taşkent’in Doğuşu. İstanbul.

Görgün, K.E., Yörür, N. (2018). Village Design Guides as Tools For Conserving The Original Tissues of Rural Settlements: The Case of Ödemiş, Bademli. Turkish Academy of Sciences Journal of Cultural Inventory, 17: 25-47.

Görmüş, S., Atmış, E., Artar, M., Özkazanç, N.K., Günşen, H.B., Cengiz, S., Tekebas, S. (2015) Küre Moutains National Park Village Design Guidelines (Bartın Section). Mutlu Basım Yayın, ISBN: 978-605-9895-05-7, İstanbul.

Gürbüz, M. \& Karabulut, M. (2008). An analysis of relationships between rural migration and socioeconomic properties. Turkish Geographical Review, Issue 50, s. 37-60.

Halaçoğlu, Y. (2006). XVIII. Yüzyılda Osmanlı İmparatorluğu'nun İskân Siyaseti ve Aşiretlerin Yerleştirilmesi. Ankara: Türk Tarih Kurumu Yayınları.

İnan Emek, C. (2014). Settlement Policy in Turkey: A Study on the Organizational Structure of Settlement. Journal of Management and Economics Research, 22: 82-102.

Inan Emek, C. (2016). Immigration policies in Turkey: an examination through the lens of settlement laws. The Journal of Migration Studies, 2(3), pp. 10-33.

Kara, H. (2006). Konya-Hadim and Taşkent Turkish period architecture. Master Thesis, Selçuk University Institute of Social Sciences, Department of Art History, Konya.

Kastamonu Küre Ersizlerdere Village Design Guideline. (2015). TC North Anatolia Development Agency, Mimar Sinan Fine Arts University.

Konya İl yıllı̆̆ı, (1967), Konya Valiliği yayını, Konya.

Mathur, H. M. (2006). Resettling People Displaced by Development Projects: Some Critical Management Issues. Social Change, 36-86.

Official Gazatte (2012) Law No. 6360 (Official Gazette 2012) on the Establishment of Metropolitan Municipalities and Twenty-Seven Districts in Fourteen Provinces and Amendments to Certain Laws and Decree Laws (1) Acceptance date: 12/11/2012 6/12/2012 date and 28489 numbered Official Gazatte.

Owen, S. (1998). The role of village design statements in fostering a locally responsive approach to village planning and design in the UK, Journal of Urban Design, 3(3), 199-220.

Owen, S. (2002). Locality and community: Towards a vehicle for community based decision making in rural localities in England. Town Planning Review, 73, 1-21.

Öğdül, H., Kap Yücel, S.D., Ünsal, B.Ö., Aksümer, G. (2018). New Planning Tools in Rural Areas: Village Design Framework, Village Design Guide and Action Projects. Planning, (Additional Issue 1): 52-72. Mimar Sinan Fine Arts University, Department of City and Regional Planning, İstanbul.

Özdemir, G. (2015). Village design guidelines and rural landscape planning strategy sample Denizli. Bartın University Institute of Natural Sciences department of Landscape Architecture, Master Thesis, Bartın.

Sak, İ. (1997). Osmanlı Döneminden Günümüze Hadim. Türkiyat Araștırmalar Dergisi, Issue: 4,p: 171, Konya. 
Büyükșahin, S. (2020). Involuntary (forced) migration in rural settlements and resettlement: Case of Konya - Bozkır Barrage Resettlement. Journal of Human Sciences, 17(4), 1014-1031. doi:10.14687/jhs.v17i4.6071

Scudder, T. \& Colson, E. (1982). From Welfare to Development: A conceptual Framework for the Analysis of Dislocated People. A. Hansen, \& A. Oliver- Smith, Involuntary Migration and Resettlement - The Problems and Responses of Dislocated People (267-287). Boulder, Colorado: Westview Press.

Tanoğlu, A. (1966). Beşeri Coğrafya, Nüfus ve Yerleşme. İstanbul Üniversitesi Yayınları No:1183, İstanbul.

Tekeli, İ. (1990). Osmanlı İmparatorluğueendan Günümüze Nüfusun Zorunlu Yer Değiştirmesi ve İskân Sorunu. Toplum ve Bilim, 50: 49-71.

Tekeli, İ. (2011). Anadolu'da Yerleşme Sistemi ve Yerleşme Tarihi, Tarih Vakfı Yurt Yayınları, İstanbul.

Tercan, B. (2008). Relocation and resettlement policies on disaster areas: The case of Doğubayazit province and four villages. PhD Thesis, Ankara University Institute of Social Sciences, Ankara.

Turan, O. (1984) Selçuklular Zamanında Türkiye Tarihi. İstanbul.

Tuzcu, P. (2008). The changing aspects of the forced migration in global era: The case of Turkey. Master thesis, Kocaeli University Institute os Social Sciences, Kocaeli.

Tümertekin, E. \& Özgüç, N. (2004). Beşeri Coğrafya, İnsan, Kültür, Mekân. Çantay Kitabevi, İstanbul.

Ünalan, T. (1998). Türkiye'de İç Göçe İlişkin Veri Kaynaklarının Değerlendirilmesi. Türkiye'de İç Göç Sorunsal Alanlar ve Araștrrma Yöntemleri Konferansı. Ahmet İçduygu- İbrahim Sirkeci- İsmail Aydıngün (Ed.), Türkiye Ekonomik ve Toplumsal Tarih Vakfi Yayınları, İstanbul, s. 91-103.

Yenigül, S. B. (2005). Göçün Kent Mekânı Üzerine Etkileri. Gaz̧i Üniversitesi Fen Bilimleri Dergisi, 18(2), s. $273-288$.

Yilmaz, M. (1990). Historical Geography of Bozkır and Environment. Master Thesis. Selçuk University. Institute of Social Sciences. Konya.

Yilmaz, H. (2007). Human and economic geography of Hadim country, Master Thesis, Selçuk University Institute of Social Sciences, Konya.

WEB1 - http://www.dsi.gov.tr/haberler/2020/08/28/bozk\%C4\%B1r-baraj\%C4\%B1-su-tutmaya$\mathrm{ba} \% \mathrm{C} 5 \% 9 \mathrm{Flad} \% \mathrm{C} 4 \% \mathrm{~B} 1$

WEB2 - https://www.haberler.com/konya-bozkir-baraji-insaati-yariyi-gecti-5162178-haberi/

WEB3 - http://dsi.gov.tr/haberler/2017/05/24/-bozk\%C4\%B1r-baraj\%C4\%B1-i-

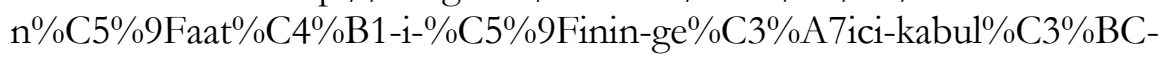
уар $\% \mathrm{C} 4 \% \mathrm{~B} 1 \mathrm{ld} \% \mathrm{C} 4 \% \mathrm{~B} 1$

WEB4

konya nin bu mahallesi tasiniyor iste tasinacagi yer ve nedeni-517847.html

WEB5 - https://yapiisleri.csb.gov.tr/iskan-calismalarimiz-yurdun-dort-yaninda-devam-ediyorhaber-228835

WEB6

http://www.yatirimlar.com/haber-

YIGMKonya Bozkir Baraji Iskani Insaati icin Sozlesme Imzaladi-276325.htm

WEB7 - http://www.yapiprojeleri.com/Proje/konya-bozkir-baraji-iskani-insaati--217856

WEB8 - http://dedemliseyder.com/foto-galeri/tr/foto-galeri

WEB9 - https://yapiisleri.csb.gov.tr/iskan-calismalarimiz-yurdun-dort-yaninda-devam-ediyorhaber-228835\#group1-17 